\title{
Impact of Insect Pollinators on Quantitative and Qualitative Improvement in Agricultural Crops: A Review
}

\author{
Paras Kumar $^{1 *}$, Gagandeep Singh ${ }^{2}$ and Harpinder Singh ${ }^{1}$ \\ ${ }^{1}$ College of Agriculture, Baba Farid College, Bathinda, Punjab, India \\ ${ }^{2}$ Division of Nematology, Indian Agricultural Research Institute, New Delhi, India \\ *Corresponding author
}

\section{A B S T R A C T}

\begin{tabular}{|l||}
\hline K e y w o r d s \\
Pollinators, Bees, \\
Quality, Quantity \\
and Agricultural \\
crops
\end{tabular}

\section{Introduction}

As we know the importance and role of insects as pollinators in agriculture sector. As a quote of eminent scientist Albert Einstein "If the bees disappeared off the surface of the globe then man would have only four years of life left", gives us an idea about how much important is honey bee for the human kind. Food requirements of world are dependent to agriculture produce. To produce quantitative food in agricultural crops, it requires pollination for adequate fruit setting. For complete fertilization in sexual reproduction it requires transformation of pollen from male part to the female part of flowers. Pollination is the process of dispersal or transformation of pollen from anther (male part of the flower) to the stigma (female part of the flower). Movement of pollen from one flower to another require vector. Both abiotic and biotic factors are responsible for pollination. Abiotic pollination occurs with the involvement of non-living agents i.e. wind, rain and water on the other hand biotic pollination occurs through the involvement of living agents i.e. insects (entomophily) and birds (ornithophily). Among animals insects plays 
vital role in pollination (Shivanna, 2015). Pollinators i.e. honeybees, bumble bee, pollen wasps, ants, etc., are required in cross pollination for pollen dispersal. Hence, pollinators have a major role in relation to crop production, declining in pollinators can reduce food production of the world. Crops are pollinated more efficiently by wild insects and fruit setting in 41 crops is positively linked with insect visitations in the crop fields (Garibaldi et al., 2013). Pollination in 80\% Angiosperms depends on animals, including bats, butterflies, beetles, flies and other insects (Committee 2007). About 108 (51.2\%) Indian agricultural crops were reported to be pollinated by animals (Chaudhary and Chand, 1017). Contribution of insects in global food production ranges between $15 \%$ and $30 \%$ (Halder et al., 2019). The order Lepidoptera (11 species) found to be more prominent, followed by Hymenoptera (5 species) for pollination of rabi crops on the other hand orders Diptera (1 species) and Coleoptera (1 species) were less prominent. Nymphalidae family of order Lepidoptera reported to be more diverse having 6 species followed by Pieridae which got 3 species (Das et al., 2018). Insect pollinates about $75 \%$ crop species. Most of the pollinator insects are from order hymenoptera and the order is known as most beneficial order of class insecta. Among order hymenoptera, most flower visiting insects are honey bees (Kumar et al., 2016). The pollinator insects act as a yield improving agents due to their assistance in cross pollination. 17 different species of selected crops were reported to be visited by 50 species of insects during flowering periods. $80 \%$ pollination achieved by insects and among the insect $80 \%$ offered by bees (Thapa, 2006). Total 55 species of insects and two vertebrates (Birds) are reported to be not only flower visitors, but better pollinators for direct human consumable 107 global crops. Among these, bees plays dominant role in pollination i.e. 47 bee species including honey bees, stingless bees, solitary bees and bumble bees are master pollinators (Klein et al., 2007). Insect pollinators are responsible for maintaining the yield and genetic variability in accompanying with sexual reproduction and reducing inbreeding depression in crops (Stein et al., 2017). Our study seeks to understand that, whether insect pollinators influence to crop yield or also to quality. For better understanding of contribution of insects to improve quality and quantity of agricultural produce empirical view is given below.

\section{Impact of pollinator insects on quantitative and qualitative improvement in agricultural crops}

Insect pollinator insects impacted the quality and quantity of agricultural crops. Transformation of nectar and pollen from one flower to another flower in agricultural and horticultural crops occurs with the help of insect pollinators. Horticultural crops i.e. aonla, phalsa, ber, pomegranate, citrus, fig, bael, jamun, field bean, citrus, cucurbits and khejri etc. are highly cross pollinated in nature, so intervention of pollinator insects is mandatory to improve the yield and quality of these crops (Haldhar et al., 2018). Papaya plants are cross pollinated by insects and wind. Insect pollinators for papaya are honey bees, wasps, midges, thrips, syrphid flies, and butterflies (Crane, 2013) (Fig. 1). It is estimated that out of 300 commercial crops $84 \%$ pollinated by insects. Escalation in yield of apple, niger, onion and faba bean by honey bees is reported an account of $33-84 \%$ (Bareke and Addi, 2019). Bumble bee performs efficient pollination as it visits on more flowers per unit time as compared to honey bees (Wahengbam et al., 2019). Benefit of insects in self-incompatible cruciferous crops was explained where crosspollination performed by insects (Sihag, 1985). Petunia bears the flower during spring and summer seasons. Open floral structure of 
petunia convenient to insect pollinators. Flower reachable to insect pollinators had larger amount of seed set, number of seeds per flower and number of seeds per plant as compared to caged flowers. Insect contribute about 92,82 and $59 \%$ in number of seeds production per plant, seed setting and number of seeds/flower respectively, in petunia (Vighi et al., 2010). Stein et al., 2017 reported increment in both quality and quantity of cotton and sesame due to pollination by bees. In cotton, under bee-mediated outcrosspollination, the increment in yield (27-31\%), seed weight and fiber weight was reported. These crops produce good quality seeds in relation of germination, vital and viability in out cross-pollinated conditions. Silva et al., 2017 reported escalation in weight and number of seed of tomato Solanum lycopersicum fruit due to activity of Exomalopsis analis, Trigona Spinipes and Apis mellifera as pollinators in tomato Solanum lycopersicum in contrary to crop pollinated without insects(self pollination). Garratt et al., 2018 observed significant yield improvement i.e. $40 \%$ in Brassicae napus from insect pollination due to increment in seeds per plant as compare to non insect pollination at higher doses of fertilizers. There was more number of seeds/pod in insect pollinated field in contrary to pollinator excluded field. Study conducted on impact of insect pollinator on yield and fruit quality of strawberry by Abrol et al., (2019) showed complete dependence on insect pollinators. There was more fruit set in strawberry in open pollination (70\%) in contrary to self pollination $(45 \%)$. Well formed larger sized red colored fruit of heavy weight $(15.25 \mathrm{~g})$ obtained from insect pollinated treatment on the other hand, misshaped small sized partial red fruit of less weight (12.24g) obtained from treatment that did not received any intervention of insects. More malformed $(17.44 \%)$ fruit were got in controlled treatment in comparison with those got from open pollinated (11.20\%). Physico-chemical characteristics i.e. specific gravity, volume, the acidity and the TSS of strawberry fruits were better in open pollinated plots. Bees (Apis mellifera L.) and solitary wild bee (Osmia bicornis L) shows the constructive influence on commercial value, commercial grade, fruit weight, shelf life and post harvest quality of strawberry Fragaria $x$ ananassa. Shelf life of strawberry is improved with firmness which was higher in bee pollinated treatment as compare to wind and selfpollination. Findings showed that $40.4 \%$, $29.4 \%$ and none of fruits were in marketable condition in bee-pollinated, wind-pollinated and self-pollinated treatment respectively after three days of storage. Similarly, higher numbers of fertilized achenes and harsh red colored fruits derived from bee pollinated experiment (Klatt et al., 2013). Almond (Prunus dulcis) requires pollinators, since it is cross pollinated crop due to self incompatibility. It is mainly pollinated by honey bees (Apis mellifera) (Connel, 2000). Saez et al., (2020) endorse to use of bees for yield improvement even in pollinator independent varieties (Self-fertile) of almond due to positive effect of bee disturbance on fruit setting. They estimated approximately $60 \%$ and $20 \%$ higher fruit setting and kernel yield respectively in bee-pollinated trees in contrast to trees that were not received bees as pollinators. It is perceived from the study of Bartomeus et al., (2014) that pollination by honey bee increases yield in field bean (Vicia faba), buck wheat (Fagopyrum esculentum), strawberry (Fragaria $x$ ananassa) and oilseed rape (Brassica napus). Quality i.e. oil content in oilseed rape and percentage of filled seed in buck wheat was boosted in open pollinated treatment than the net treatment (no insect pollinators). Globally, onion is a prime vegetable. Higher seed yield is fundamental principle of in commercial seed production programs. Study conducted by Padamshali and Mandal (2018) in West Bengal revealed 
that honey bees are act as yield improving input in onion. Seed yield and seed weight of onion was higher in honey bee pollinated crop. Immense influence of pollinator insects was reported in germination percentage of onion seeds. Germination percentage of seeds obtained from bee pollinated crop was higher (i.e. 76\%) than seed obtained from non-insect pollinated crop (i.e. 14\%). Shakeel and Inayatullah (2013) reported 9 species of bees and flies foraging/visiting in canola $(B$. napus) ecosystem which were proved to be advantageous in increasing of yield of canola crop. Number of seed per siliqua, number of siliquae per plant and seed weight (per 100 seeds) was $15,189.3$ and $0.55 \mathrm{~g}$ respectively in open pollinated plot and 11, 142.2 and $0.35 \mathrm{~g}$ respectively in covered plot (without insect pollinators). Razzaq et al., (2019) confirmed improvement in seeds/plant, pods/plant and weight of 100 pods in canola plants which were caged with pollinators i.e. honey bees. Seeds/plant, pods/plant and weight of 100 pods (in gm) was 828, 67 and $4.42 \mathrm{~g}$ respectively in plants caged with honey bees and 626, 47 and 3.53g was respectively in plants caged without honey bees. Another study conducted on toria (Brassica campestris L. var. toria) in Nepal revealed that honey bee pollination improve siliqua/plant, seeds/siliqua, grain weight and seed yield of toria in contrary to restricted pollination (Rijal et al 2017). Investigations of ATMOVIDI et al (2007) on seed setting of Brassica rapa in Indonesia signify that insect pollinator especially bees had great influence on yield. Increment in racemes/plant, seeds/pod, pods/plant, seed weight and seeds/plant by 65.6, 98.2, 178.8, 931.9 and $932.5 \%$ respectively, was observed in plants which were pollinated by diverse insect species. Furthermore, seed germination of B. rapa was also higher for seed obtained from insect pollinated treatment (i.e. $92.72 \%$ ) than that of obtained from caged plant (i.e. 90.30\%). Study conducted on role of honey bee on mustard yield in Kota, Rajasthan showed the effectiveness of honey bees during 2013-14 and 2014-15. Experiments conducted on three modes of pollination viz. bee pollination, open pollination and pollinator exclusion (No pollinators). In both seasons, bee pollination enhances the yield in comparison with pollinator exclusion. Yield of mustard was 1785,2040 and $1509.38 \mathrm{~kg} / \mathrm{ha}$ in bee pollinated, open pollinated and pollinator exclusion treatments, respectively during 2013-14 and 1875, 2068.75 and $1577 \mathrm{~kg} / \mathrm{ha}$ respectively during 2014-15. Mean number of siliqua/plant and number of seeds/siliqua was also higher in open pollination followed by bee pollination and lower in pollinator exclusion (Patidar et al 2017). Insect pollinators were able to increase number of flowers/plant, no. of seeds/plant, seed weight and oil content percent in oilseed rape, Brassica napus in Sweden. Seed weight and oil content and market value per plant was higher in plants in which flowers were accessible to insect, self and wind pollination in contrast to plants were accessible to self and wind pollination rather than insects (Bommarco et al 2012). It was elucidated from the study of Sihag RC (1986) conducted at Hisar (India), that bees were chief pollinators for increasing seed production in cruciferous and umbelliferous crops. Insects contribute to increase seed yield for about 1.8 times. Pod length, seed weight, number of seed/pod, pods per plant and seed yield of cruciferous crops (i.e. B. juncea, Brassica campestris var. toria, B. carinata, B. napus, B. juncea, B. oleracea L. var. botrytis, Eruca sativa, Raphanus sativus and B. rapa) and umbelliferous crops (i.e. Foeniculum vulgare, Coriander sativum, Daucus carota L. var. sativa and Cuminum cyminum) were higher in case of crop exposed to insect pollinators than caged crop. In another study, impact of pollinator insects on crop yield of mustard conducted during 2018-19 in Nepal showed that Hymnopteran insects followed by 
Dipteran insects played crucial role in pollination of mustard, since mustard is cross pollinated crop. Average fruit set, seeds per pod, number of pods, diameter of seed and seed weight were $70.55 \%, 16.70,59.60$, $0.13 \mathrm{~mm}, 0.33 \mathrm{gm}$ respectively, in treatment where flower were accessible to wind and self pollination only, whereas $80.94 \%, 19.30$, $70.47 \%, 0.27 \mathrm{~mm}$ and $0.48 \mathrm{gm}$ respectively, where crop is pollinated by insect pollinators accompanied by self and wind pollination (Subedi and Subedi, 2019). Honey bees were reported to be crucial for comparatively high seed production in broccoli, Chinese cabbage, knol-khol in North-western Himalaya region of India. During 2006-07 and 2007-08 yield increasing parameters i.e. seeds/pod, seed weight and pods/panicle were greater in broccoli, Chinese cabbage, knol-khol where crops were provided especially by honey bee pollinators in comparison with natural pollination. Seed yield of Chinese cabbage, knol-khol and broccoli was 187,143 and $439.30 \mathrm{~kg} / \mathrm{ha}$ respectively, in natural pollination whereas it was 212.85, 187, $181.20 \mathrm{~kg} / \mathrm{ha}$ respectively, where pollination performed by particularly bees (Sushil et al., 2013). Findings on honey bee attractants and pollination in sweet orange, Citrus sinensis showed number of honey bee visit on crop positively correlated with fructification. Average fructification was $56.5 \%$ and $83.7 \%$ where honey bee visits were 9 and 10-15 respectively. Comparatively less acidic fruits having higher fruit weight and $35.30 \%$ higher fruit yield were obtained from bee pollinated crop (Malerbo-Souza et al., 2004).

Fig.1 Insect pollinators (Source: Das et al 2018)

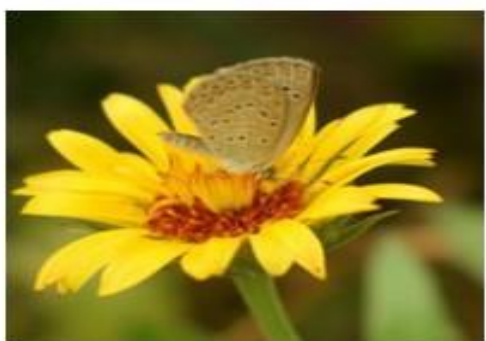

Lesser grass blue

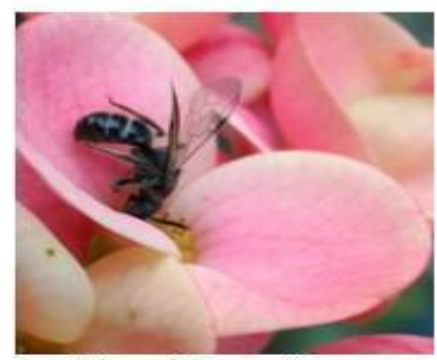

Dwarf honeybee

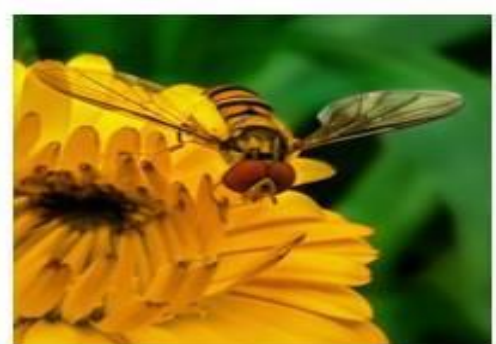

Hoverfly

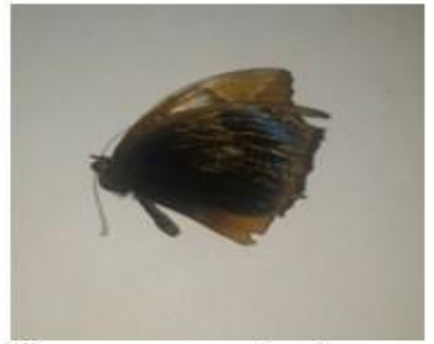

Common evening brown
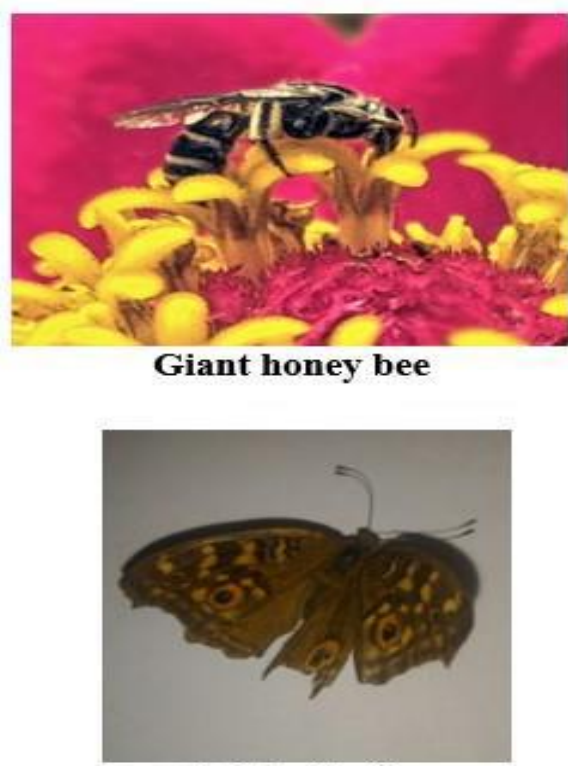

Owl butterfly

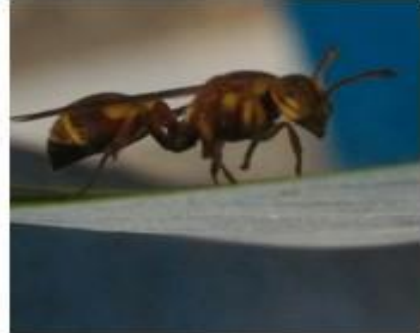

Wasp

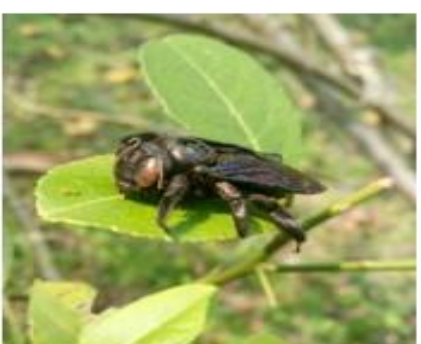

Carpenter bee 


\section{Declining in insect pollinators}

Diverse population of insect pollinators is associated with agricultural crops which promote pollination in crops and enhance the quality and quantity of agricultural produce. So diminishing in population of these pollinators may lead reduction in agricultural produce. In modern agricultural practices, use of chemical insecticides is one of the prime tactic to control the pest population but indiscriminate use of these insecticide put adverse impact on population of pollinators (Fikadu, 2020). Insect pollinators not affected only by chemical composition of pesticides, even also affected by time and method of spraying (Kumar et al 2018). Application of pesticide should be avoided at the time of flowering period of crops (Bareke and Addi 2019). Lambda-cyhalothrin 5 EC, profenofos $750 \mathrm{EC}$, diazinon $60 \mathrm{EC}$, deltamethrin $2.5 \mathrm{EC}$, endosulfan $35 \mathrm{EC}$ and malathion $50 \mathrm{EC}$ used for pest control in onion were reported to be toxic to honey bee pollinators which indirectly influence the seed yield in onion (Melisie and Damte, 2017). Wild bee performs pollination in different agricultural crops. Negative effects of conventional pesticides on abundance and species richness were appraised in apple (Malus domestica) orchard during 2011-12. Wild bee abundance and species richness were decreased one year after increasing use of pesticides. On the other hand, evaluation on influence of landscape context on wild bees revealed that wild bee abundance and species richness were positively correlated with percent of natural area including grasslands, forests and shrublands. Increasing of natural area of landscape also reduce the negative relationship of pesticides with abundance and species richness of wild bees (Park et al., 2015).

In this article, we conclude great potential of insect pollinators in production of different agricultural crops. Hence, declining in pollinators can reduce food production of the world. Insect pollinators ameliorate quality and quantity in cross pollinated as well as some of self pollinated crops and act as an agronomic input. Excess use of pesticides in an improper way causes decrease in population of pollinators in the field which indirectly affects the crop yield as well as quality of produce. Instead of chemical pesticides, there is a need to shift towards biological and other IPM methods of pest control to enhance the population of insect pollinators in crop fields. Keeping in mind potential of insect and negative consequences of pesticides, conservation of natural habitat is suggested to maintain the population and species of bee pollinators. Beekeeping should not be considered only a business but also considered as an agronomic practice for crops to produce qualitative and quantitative agricultural produce. It is recommended to the farmers to keep the beehive along with cultivation of crops.

\section{References}

Abrol, D. P., Gorka, A. K., Ansari, M. J., AlGhamdi, A., and Al-Kahtani, S. (2019). Impact of insect pollinators on yield and fruit quality of strawberry. Saudi journal of biological sciences, 26(3), 524-530.

Atmowidi, T., Buchori, D., Manuwoto, S., SURYOBROTO, B., and HIDAYAT, P. (2007). Diversity of pollinator insects in relation to seed set of mustard (Brassica rapa L.: Cruciferae). HAYATI Journal of Biosciences, 14(4), 155-161.

Bareke T, Addi A. Effect of honeybee pollination on seed and fruit yield of agricultural crops in Ethiopia. MOJ Eco Environ Sci. 2019; 4(5): 205-209.

Bartomeus, I., Potts, S. G., Steffan-Dewenter, 
I., Vaissiere, B. E., Woyciechowski, M., Krewenka, K. M., and Bommarco, R. (2014). Contribution of insect pollinators to crop yield and quality varies with agricultural intensification. Peer J, 2, e328.

Bommarco, R., Marini, L., and Vaissière, B. E. (2012). Insect pollination enhances seed yield, quality, and market value in oilseed rape. Oecologia, 169(4), 10251032.

Committee on the Status of Pollinators in North America NRC (2007) Status of pollinators in North America. National Academies Press. Washington, D.C.

Crane JH. Papaya growing in the Florida home landscape-factsheetHS11. Aseries of the Horticultural Sciences Department, Florida Cooperative Extension Service, Institute of Food and Agricultural Sciences, University of Florida. 2013, 1-6.

Das B.J., Paul K., Baruah N., and Basumatary B.K (2018). Diversity of insect pollinators of rabi crops cultivated in surrounding areas of barpeta town in Assam, India". International journal of research and analytical reviews vol.4 issue 5. 172-177

Fikadu, Z. (2020). Pesticides use, practice and its effect on honeybee in Ethiopia: a review. International Journal of Tropical Insect Science, 1-9.

Garibaldi, L. A., Steffan-Dewenter, I., Winfree, R., Aizen, M. A., Bommarco, R., Cunningham, S. A., and Bartomeus, I. (2013). Wild pollinators enhance fruit set of crops regardless of honey bee abundance. science, 339(6127), 16081611.

Garratt M, Bishop J, Degani E, et al. Insect pollination as an agronomic input: Strategies for oilseed rape production. $J$ Appl Ecol. 2018; 55: 2834-2842.

Halder S, Ghosh S, Khan R, Khan A.A, Perween T and Hasan M.A (2019).
Role of pollination in fruit crops: A review. The Pharma Innovation Journal; 8(5): 695-702

Haldhar SM, Kumar R, Samadia DK, Singh B and Singh H. 2018. Role of insect pollinators and pollinizers in arid and semi-arid horticultural crops. Journal of Agriculture and Ecology, 5: 1-25.

Klatt, B. K., Holzschuh, A., Westphal, C., Clough, Y., Smit, I., Pawelzik, E., and Tscharntke, T. (2014). Bee pollination improves crop quality, shelf life and commercial value. Proceedings of the Royal Society B: Biological Sciences, $281 \quad 20132440$. http://dx.doi.org/10.1098/rspb.2013.244 0 .

Klein $\mathrm{AM}$, Vaissière $\mathrm{BE}$, Cane $\mathrm{JH}$, et al. Global pollinator decline: a literature review. Ecology for a crowded planet, Science. 2007; 304:1251- 1252.

Klein AM, Vaissiere BE, Cane JH, SteffanDewenter I, Cunningham SA, Kremen $\mathrm{C}$ and Tscharntke T. 2007. Importance of pollinators in changing landscapes for world crops. Proceedings of the Royal Society Series B-Biological Sciences, 274: 303-313.

Kumar S., Joshi P.C., Nath P., Singh V.K., and Mansotra D.K. (2016) International Research Journal of Biological Sciences Vol. 5(1), 1-8

Malerbo-Souza, D. T., Nogueira-Couto, R. H., and Couto, L. A. (2004). Honey bee attractants and pollination in sweet orange, Citrus sinensis (L.) Osbeck, var. Pera-Rio. Journal of Venomous Animals and Toxins including Tropical Diseases, 10(2), 144-153.

Padamshali, S., and Mandal, S. K. Effect of Honey Bee (A. mellifera) Pollination on Yield and Yield Attributing Parameters of Onion (Allium cepa L.). (2018). Int.J.Curr.Microbiol.App.Sci (2018) Special Issue-7: 4843-4848

Park, M. G., Blitzer, E. J., Gibbs, J., Losey, J. 
E., and Danforth, B. N. (2015). Negative effects of pesticides on wild bee communities can be buffered by landscape context. Proceedings of the Royal Society B: Biological Sciences, 282(1809), 20150299. http://dx.doi.org/10.1098/rspb.2015.029 9

Patidar, B. K., Ojha, K. N., and Khan, I. U. (2017). Role of Honeybee (Apis mellifera) in Enhancing Yield of Mustard in Humid Region of Rajasthan, India. Int. J. Curr. Microbiol. App. Sci, 6(7), 1879-1882.

Razzaq, A., Abbasi, K. H., Jamal, M., Aslam, A., Malik, K., and Ullah, M. A. (2019). Evaluation of Pollination by Honeybee (Apis Mellifera L.) on Canola (Brassica Napus L.) Produce. International Journal of Agriculture and Plant Science Vol.1 (3), 1-5.

Rijal, S. P., Thapa, R. B., Sharma, M. D., Sah, S. K., and GC, Y. D. (2017). Pollinators diversity and their effects on rapeseed (Brassica campestris L. var. toria) production and productivity in Chitwan, Nepal. Journal of Agriculture and Environment, 18, 151-161.

Sáez, A., Aizen, M. A., Medici, S., Viel, M., Villalobos, E., and Negri, P. (2020). Bees increase crop yield in an alleged pollinator-independent almond variety. Scientific reports, 10(1), 1-7.

Shakeel, M., and Inayatullah, M. (2013). Impact of insect pollinators on the yield of canola (Brassica napus) in Peshawar, Pakistan. Journal of Agricultural and Urban Entomology, 29(1), 1-5.

Stein, K., Coulibaly, D., Stenchly, K., Goetze, D., Porembski, S., Lindner, A., and Linsenmair, E. K. (2017). Bee pollination increases yield quantity and quality of cash crops in Burkina Faso, West Africa. Scientific reports, 7(1), 110.

Subedi, N., and Subedi, I. P. (2019).
Pollinator Insects and their Impact on Crop Yield of Mustard in Kusma, Parbat, Nepal. Journal of Institute of Science and Technology, 24(2), 68-75.

Sushil, S. N., Stanley, J., Hedau, N. K., and Bhatt, J. C. (2013). Enhancing seed production of three Brassica vegetables by honey bee pollination in northwestern Himalayas of India. Universal Journal of Agricultural Research, 1(3), 49-53.

Thapa RB. 2006. Honeybees and other insect pollinators of cultivated plants: A Review. Journal of Institute Agriculture and Animal Science, 27:1-23.

Vighi, M., Settele, J., and Potts, S. G. (2010). The impact of an insecticide on insect flower visitation and pollination in agricultural landscape. Agricultural and Forest Entomology, 12, 259-266.

Vinícius-Silva, R., Parma, D. D. F., Tostes, R. B., Arruda, V. M., and Werneck, M. D. V. (2017). Importance of bees in pollination of Solanum lycopersicum L. (Solanaceae) in open-field of the Southeast of Minas Gerais State, Brazil. Hoehnea, 44(3), 349-360.

WAHENGBAM, J., Raut, A. M., Satinder, P., and Banu, A. N. (2019). Role of bumble bee in pollination. Annals of Biology, 35(2), 290-295.

Atmowidi, T., Buchori, D., Manuwoto, S., SURYOBROTO, B., and HIDAYAT, P. (2007). Diversity of pollinator insects in relation to seed set of mustard (Brassica rapa L.: Cruciferae). HAYATI Journal of Biosciences, 14(4), 155-161.

Chaudhary, O. P., and Chand, R. (2017). Economic benefits of animal pollination to Indian agriculture. Indian Journal of Agricultural Sciences, 87(9), 11171138.

Sihag, R. C. (1986). Insect pollination increases seed production in cruciferous and umbelliferous crops. Journal of Apicultural Research, 25(2), 121-126. 
Melisie, D., and Damte, T. (2017). Effects of Some Insecticides on Foraging honeybees on Onion Flowers under Field Condition. Recent Research in Science and Technology, 13-17.

Connell, J. H., Index, A. D., Prunus, W., California, S. U. and Webb, M. D. A. Pollination of almonds: practices and problems. Horttechnology, 10, 116-119 (2000).
Kumar, S., Joshi, P. C., Nath, P., and Singh, V. K. (2018). Impacts of Insecticides on Pollinators of Different Food Plants. Entomol Ornithol Herpetol, 7(2), 7.

Shivanna K. R. (2015) Management of pollination services to enhance crop productivity. In: Plant biology and biotechnology. Springer, Karnataka, pp 697-711.

\section{How to cite this article:}

Paras Kumar, Gagandeep Singh and Harpinder Singh. 2020. Impact of Insect Pollinators on Quantitative and Qualitative Improvement in Agricultural Crops: A Review. Int.J.Curr.Microbiol.App.Sci. 9(09): 2359-2367. doi: https://doi.org/10.20546/ijcmas.2020.909.295 